\title{
Turnover of Amyloid $\beta$-Protein in Mouse Brain and Acute Reduction of Its Level by Phorbol Ester
}

\author{
Mary J. Savage, Stephen P. Trusko, David S. Howland, Leonard R. Pinsker, Suzanne Mistretta, \\ Andrew G. Reaume, Barry D. Greenberg, Robert Siman, and Richard W. Scott
}

Cephalon, Inc., West Chester, Pennsylvania, 19380

Fibrillar amyloid deposits are defining pathological lesions in Alzheimer's disease brain and are thought to mediate neuronal death. Amyloid is composed primarily of a 39-42 amino acid protein fragment of the amyloid precursor protein (APP), called amyloid $\beta$-protein $(A \beta)$. Because deposition of fibrillar amyloid in vitro has been shown to be highly dependent on $A \beta$ concentration, reducing the proteolytic release of $A \beta$ is an attractive, potentially therapeutic target. Here, the turnover rate of brain $\mathrm{A} \beta$ has been determined to define treatment intervals over which a change in steady-state concentration of $A \beta$ could be measured. Mice producing elevated levels of human $A \beta$ were used to determine approximate turnover rates for $A \beta$ and two of its precursors, C99 and APP. The $t_{1 / 2}$ for brain A $\beta$ was between 1.0 and $2.5 \mathrm{hr}$, whereas for C99, immature, and fully glycosylated forms of APP695 the approximate $t_{1 / 2}$ values were 3,3 , and $7 \mathrm{hr}$, respectively. Given the rapid $\mathrm{A} \beta$ turnover rate, acute studies were designed using phorbol 12-myristate 13-acetate (PMA), which had been demonstrated previously to reduce $A \beta$ secretion from cells in vitro via induction of protein kinase $C$ (PKC) activity. Six hours after intracortical injection of PMA, A $\beta$ levels were significantly reduced, as measured by both $A \beta 40$ and $A \beta 42$-selective ELISAs, returning to normal by $12 \mathrm{hr}$. An inactive structural analog of PMA, $4 \alpha-$ PMA, had no effect on brain $A \beta$ levels. Among the secreted $\mathrm{N}$-terminal APP fragments, APP $\beta$ levels were significantly reduced by PMA treatment, whereas $\operatorname{APP} \alpha$ levels were unchanged, in contrast to most cell culture studies. These results indicate that $A \beta$ is rapidly turned over under normal conditions and support the therapeutic potential of elevating PKC activity for reduction of brain $A \beta$.

Key words: protein turnover; amyloid- $\beta$ protein; amyloid precursor protein; Alzheimer's disease; phorbol ester; protein kinase $C$
The behavioral deficits associated with Alzheimer's disease (AD) result from the loss of neurons and synapses, primarily in the cortex and hippocampus. Amyloid deposits in these regions are an invariant pathological feature of $\mathrm{AD}$ and result from the aggregation of a 39-42 amino acid long protein known as amyloid $\beta$-protein (A $\beta)$ (Selkoe, 1996). This protein has been shown to be neurotoxic in vitro when present in an aggregated form (Pike et al., 1993). Evidence obtained from the study of familial forms of AD in which mutations exist in either the amyloid precursor or presenilin genes (Hardy, 1997) implicates elevated secretion of the 42 amino acid form as a likely etiological event in disease development. This form is most fibrillogenic in vitro (Jarrett et al., 1993) and is more abundant in amyloid deposits in the AD brain than shorter, less fibrillogenic forms (Iwatsubo et al., 1994; Savage et al., 1995; Yamaguchi et al., 1995). Under normal conditions, however, soluble $\mathrm{A} \beta$ ending at residue 40 is more abundant than the 42 residue form (Haass et al., 1992; Seubert et al., 1992; Shoji et al., 1992; Vigo-Pelfrey et al., 1993).

The amyloid precursor protein (APP) is processed to form $\mathrm{A} \beta$ and other derivatives by at least three proteases, identified by their cleavage specificities (Selkoe, 1996). $\alpha$-Secretase generates a secreted N-terminal APP fragment $(\operatorname{APP} \alpha)$ and also destroys the

Received Oct. 8, 1997; revised Dec. 9, 1997; accepted Dec. 15, 1997.

We thank Drs. Matthew Miller, Bruce Jones, and Dorothy Flood of Cephalon and Dr. Jim Krause of Washington University for discussions that helped initiate this work, Thomas Emmons for help with preparation of figures, Renee Simmons and Edwin McCabe for their excellent care of the gene-targeted animals, and Drs. Frank Baldino and Jeffry Vaught for their continuing support of this work.

Correspondence should be addressed to Dr. Mary Savage, Cephalon, Inc., 145 Brandywine Parkway, West Chester, PA 19380.

Copyright (C) 1998 Society for Neuroscience $0270-6474 / 98 / 181743-10 \$ 05.00 / 0$
$\mathrm{A} \beta$ domain. The remaining $\mathrm{C}$-terminal fragment $(9 \mathrm{kDa})$ can be processed further by $\gamma$-secretase, leading to the secretion of a 3 $\mathrm{kDa}$ protein $(\mathrm{P} 3)$ and formation of a $6 \mathrm{kDa} \mathrm{C}$-terminal fragment retained by the cells. $\beta$-Secretase cleaves APP at the $\mathrm{N}$ terminus of $\mathrm{A} \beta$, leading to the secretion of an $\mathrm{N}$-terminal fragment (APP $\beta$ ) that is 16 residues shorter than $\mathrm{APP} \alpha$ and a cell-associated, $\mathrm{C}$-terminal fragment (C99) that can be processed further by $\gamma$-secretase to generate the $\mathrm{C}$ terminus of the $\mathrm{A} \beta$ protein.

To develop an experimental system in which to measure pharmacological effects on APP processing in vivo, we have used a gene-targeted mouse harboring the Swedish familial Alzheimer's disease (FAD) mutation and a humanized $\mathrm{A} \beta$ domain (Reaume et al., 1996). These mice express readily detectable levels of human $\mathrm{A} \beta$ and, unlike conventional APP transgenic animals, express endogenous levels of APP under normal developmental and tissue-specific control. In this model, we previously demonstrated increased cleavage at the $\beta$-secretase site, a finding well documented in vitro in FAD model systems (Citron et al., 1992; Cai et al., 1993; Citron et al., 1994).

Knowledge of $\mathrm{A} \beta$ turnover rate in vivo is necessary to determine treatment intervals over which a change in $\mathrm{A} \beta$ levels could be measured. Here, we demonstrate that mechanisms are present in mouse brain that eliminate $\mathrm{A} \beta, \mathrm{C} 99$, and APP within several hours of their generation. This knowledge was exploited to initiate studies of agents that could lower $A \beta$ levels in the brain. Phorbol 12-myristate 13-acetate (PMA) has been used extensively in vitro to modulate APP processing and, as a result, lower secreted A $\beta$ levels (Buxbaum et al., 1992; Hung et al., 1993). This compound is highly selective for the activation of protein kinase C (PKC) (Newton, 1995) and has been used previously to mod- 
ulate brain processes in vivo (Cope et al., 1984; Routtenberg et al., 1986; Baranyi et al., 1987; Deitrich et al., 1989). Here, intracortical injections of PMA resulted in short-term reductions in $\mathrm{A} \beta$ levels in mouse brain, thus validating in vivo the modulatory effect of PKC activation on $\mathrm{A} \beta$ secretion that has been described in cultured cell systems. We have extended these observations by demonstrating specific effects on levels of both $\mathrm{A} \beta 40$ and $\mathrm{A} \beta 42$. Interestingly, we did not observe increased APP $\alpha$ concentrations in brain coincident with the reduction in levels of $\mathrm{A} \beta$, contrary to effects of PMA seen in cell culture. This highlights the importance of measuring $\mathrm{A} \beta$ levels directly, as well as other APP derivatives, when evaluating modulators of APP metabolism in vivo.

\section{MATERIALS AND METHODS}

Antibodies. Rabbit polyclonal antibody 1153 was generated against the first 28 amino acids of human A $\beta$ (Savage et al., 1994). Monoclonal antibody 6E10 and biotinylated 6E10 were both purchased from Senetek (Maryland Heights, MO) and recognize an epitope within A $\beta 1-17$. Rabbit polyclonal antibody 97 was directed against the 30 amino acids at the $\mathrm{C}$ terminus of APP (Reaume et al., 1996). A $\beta 40$ - and A $\beta 42$-selective polyclonal antibodies (affinity-purified; A $\beta 40$, lots 4434804, 4434805, 4434806, and 4434807; A $\beta 42$ lot 4434417) were obtained from Quality Controlled Biochemicals (Hopkinton, MA). Polyclonal antibody 54 was generated against the peptide sequence SEVNL and is specific for Swedish FAD mutant APP $\beta$ (Siman et al., 1995). A monoclonal antibody against actin (clone C4) was purchased from Boehringer Mannheim (Indianapolis, IN). Both goat anti-rabbit and goat anti-mouse $\mathrm{IgG}_{1}$ were purchased from Southern Biotechnology Associates (Birmingham, AL).

Infusion of $\left[{ }^{35}\right.$ S]methionine into gene-targeted mice. Mice at 6 months of age were anesthetized with a mixture of $120 \mathrm{mg} / \mathrm{kg}$ ketamine and 12 $\mathrm{mg} / \mathrm{kg}$ xylazine. $\left[{ }^{35} \mathrm{~S}\right]$ Methionine (New England Nuclear, Boston, MA) at $500 \mu \mathrm{Ci} / 100 \mu \mathrm{l}$ (with $0.9 \%$ saline diluent) was infused into the femoral vein of each mouse over $30 \mathrm{~min}$. Rate and volume of infusion were chosen to approach steady-state plasma levels of isotope (Garlick and Marshall, 1972). At various time points after the midpoint of the infusion, mice were anesthetized with avertin (1.25\% 2,2,2-tribromoethanol and $2.5 \%$ 2-methyl-2-butanol), and blood was withdrawn via intraventricular puncture. The mice were then perfused with $15 \mathrm{ml}$ of Ringer's solution at room temperature over $5 \mathrm{~min}$, and brains were removed, rapidly frozen, and stored at $-70^{\circ} \mathrm{C}$.

Detection of radiolabeled and steady-state $A \beta, C 99$, and APP. Brain supernatants were processed for immunoprecipitation as described previously (Reaume et al., 1996). Briefly, brains were homogenized in $6 \mathrm{~m}$ guanidine and $50 \mathrm{~mm}$ Tris, $\mathrm{pH} 7.5$, and centrifuged at $100,000 \times \mathrm{g}$, and supernatants were dialyzed against PBS with protease inhibitors. From three-fourths of the dialysate, $\mathrm{C} 99$ and $\mathrm{A} \beta$ were immunoprecipitated using the polyclonal antiserum 1153 and Pansorbin (Calbiochem, San Diego, CA). From the remaining one-fourth of the dialysate, APP was immunoprecipitated using polyclonal antiserum 97. Proteins immunoprecipitated with antiserum 1153 were resolved by electrophoresis on 10-20\% Tris-tricine polyacrylamide gels (Owl Scientific, Woburn, MA) and transferred to a polyvinylidene difluoride membrane. Proteins immunoprecipitated using antiserum 97 were resolved using Laemmli gels (4-20\%, Owl Scientific) and transferred to nitrocellulose. Dried membranes were exposed to phosphorimage screens (Molecular Dynamics, Sunnyvale, CA). Relative intensities of protein bands were determined using ImageQuant software (Molecular Dynamics).

After exposure of the phosphorimage screen to detect radiolabeled proteins corresponding to $\mathrm{A} \beta, \mathrm{C} 99$, and APP, steady-state levels of these proteins were detected by immunoblotting. Membranes were wetted with transfer buffer and blocked with 5\% nonfat dry milk in Tris-buffered saline (TBS). Monoclonal antibody 6E10 and enhanced chemiluminescence were used to detect these APP forms as described previously (Reaume et al., 1996).

Treatment of mice with phorbol ester. Gene-targeted mice from 3-6 months of age were anesthetized with ether. PMA (40 nmol) or $4 \alpha$ PMA $(40 \mathrm{nmol})$ (phorbol esters from Alexis Biochemicals, San Diego, CA) or a corresponding volume of vehicle $(2.5 \mu \mathrm{l}, 30 \%$ DMSO and $0.9 \%$ saline $)$ was injected unilaterally into the parietal cortex, $2.5 \mathrm{~mm}$ down from the surface of the head. Six or $12 \mathrm{hr}$ later, animals were anesthetized with avertin, brains were removed, and parietal cortex samples from both hemispheres were Dounce-homogenized together in $2 \mathrm{ml}$ of $0.2 \%$ diethylamine (DEA) and $50 \mathrm{~mm} \mathrm{NaCl}$. Brain homogenates were centrifuged at $100,000 \times g$, and recovered supernatants were neutralized to $\mathrm{pH} 8.0$ with $2 \mathrm{M}$ Tris-HCl. Extracts were diluted 1:1 with $5 \%$ fetal clonal serum (HyClone, Logan, UT) and 1\% nonfat dry milk in TBS and analyzed for $\mathrm{A} \beta$ concentration using the ELISAs described below.

AB40- and 42-specific ELISAs. For the 40-specific ELISA, Fluoronunc plates (Nunc, Naperville, IL) were coated with goat anti-rabbit IgG at $1: 300$ in $0.1 \mathrm{~m}$ sodium bicarbonate. This was followed by an A $\beta 40$ selective polyclonal antibody at 1:300 in 5\% fetal clonal serum and $1 \%$ nonfat dry milk in TBS. The wells were blocked further in this same solution, without antibody. Tween $20(0.1 \%)$ in TBS was used as the wash solution between each indicated step. Brain DEA extracts containing A $\beta$ were diluted 1:1 in blocking solution and applied to the plates overnight at $4{ }^{\circ} \mathrm{C}$. $\mathrm{A} \beta$ was detected using biotinylated $6 \mathrm{E} 10$ at 1:5000 and avidinalkaline phosphatase (Cappel/ICN, Costa Mesa, CA) at 1:500. Bound phosphatase was detected using 4-methyl umbelliferyl phosphate (4MeUP; Sigma, St. Louis, MO) and read at 360/460 nm. Specificity of this ELISA for $\mathrm{A} \beta 1-40$ was tested using recombinant $\mathrm{C} 100$ (comprising the last 100 amino acid residues of APP; Savage et al., 1994), A $\beta 1-42$, or A $\beta 1-43$ (Bachem, King of Prussia, PA). These proteins were added to standard curves comprising A $\beta 1-40$ (Bachem), and their ability to alter the curve was determined. ELISA signals are reported as femtomoles of $\mathrm{A} \beta$ per milligram of total extracted protein based on $\mathrm{A} \beta$ standard curves generated in each experiment.

The design of the 42-selective ELISA was the same, except the capture antibody was $6 \mathrm{E} 10$ and the detecting antibody was selective for $\mathrm{A} \beta 42$. Fluoronunc plates were coated with goat anti-mouse $\mathrm{IgG}_{1}$ as described above. Monoclonal antibody 6E10 was used at 1:1000 in 5\% fetal clonal serum and $1 \%$ nonfat dry milk, followed by an additional block in 5\% nonfat dry milk in TBS. Intermediate washes were as above. Brain DEA extracts were diluted in blocking solution and applied for overnight capture at $4^{\circ} \mathrm{C}$. A $\beta 42$ was detected using the 42 -specific polyclonal antibody at 1:200, followed by a goat anti-rabbit IgG-alkaline phosphatase conjugate (Southern Biotechnology Associates, Birmingham, AL) at 1:5000. 4-MeUP substrate was used as above. Specificity of this ELISA for $\mathrm{A} \beta$ was tested by comparing signals generated with $\mathrm{A} \beta 1-40$, $\mathrm{A} \beta 1-43$, and recombinant $\mathrm{C} 100$ with signals generated using $\mathrm{A} \beta 1-42$.

Because C99 and APP could also bind to the 6E10 capture antibody used in the 42-specific ELISA and are present at much higher concentrations than $\mathrm{A} \beta 42$ in the mouse brain, we examined DEA extracts for the presence of C99 and APP. Neutralized DEA extracts were adjusted to $1 \times$ radioimmunoprecipitation assay buffer $(50 \mathrm{~mm}$ Tris base, $\mathrm{pH} 8.0$, $150 \mathrm{~mm} \mathrm{NaCl}, 1 \%$ Triton $\mathrm{X}-100,0.25 \%$ sodium deoxycholate, $0.1 \%$ sodium dodecyl sulfate, $2 \mathrm{~mm}$ EDTA, and $1 \mathrm{~mm}$ benzamidine) and immunoprecipitated with $\mathrm{Ab} 97$ and Pansorbin overnight at $4^{\circ} \mathrm{C}$. Some samples were spiked with $5 \mathrm{ng}$ of recombinant C100. Precipitated proteins were electrophoresed on 10-20\% Tris-tricine gels or 4-20\% Laemmli gels (both from Owl Scientific) to visualize C99 or APP, respectively. Proteins were immunoblotted and detected using 6E10 and ECL as above.

Detection of $A P P \alpha$ and $A P P \beta$. From the DEA extracts described above, $250 \mu \mathrm{g}$ aliquots of protein from each sample were methanolprecipitated for $1-2 \mathrm{hr}$ at $-20^{\circ} \mathrm{C}$. Precipitates were air-dried and resuspended in equal volumes of Laemmli sample buffer. Aliquots of each sample $(50 \mu \mathrm{g})$ were electrophoresed in triplicate using 4-20\% Laemmli gels and transferred to nitrocellulose. Membranes were blocked using 5\% nonfat milk powder in TBS and incubated with either $6 \mathrm{E} 10$ at 1:2000 or 54 at 1:500 for detection of $\operatorname{APP} \alpha$ or $\operatorname{APP} \beta$, respectively. Relative band intensity (visualized using ECL as described above) was determined using a Docugel V Scanalytic system (CSP, Inc., Billerica, MA). As a control for protein loading and transfer variabilities between samples, immunoblots were stripped using $100 \mathrm{~mm} \beta$-mercaptoethanol and $2 \% \mathrm{SDS}$ at $37^{\circ} \mathrm{C}$ for $1 \mathrm{hr}$ and reblotted using a monoclonal anti-actin antibody at 1:2000. Band densities representing secreted APP fragments were then normalized to the actin signal densities contained within each respective sample.

\section{RESULTS}

\section{Radiolabeling in vivo}

We have studied the metabolism of $\mathrm{C} 99, \mathrm{~A} \beta$, and APP in vivo using infusion of $\left[{ }^{35} \mathrm{~S}\right]$ methionine into the femoral vein of the gene-targeted mouse. The turnover of all examined species occurs within $1 \mathrm{~d}$. Identity of these three proteins (Figs. 1, 2) is confirmed 


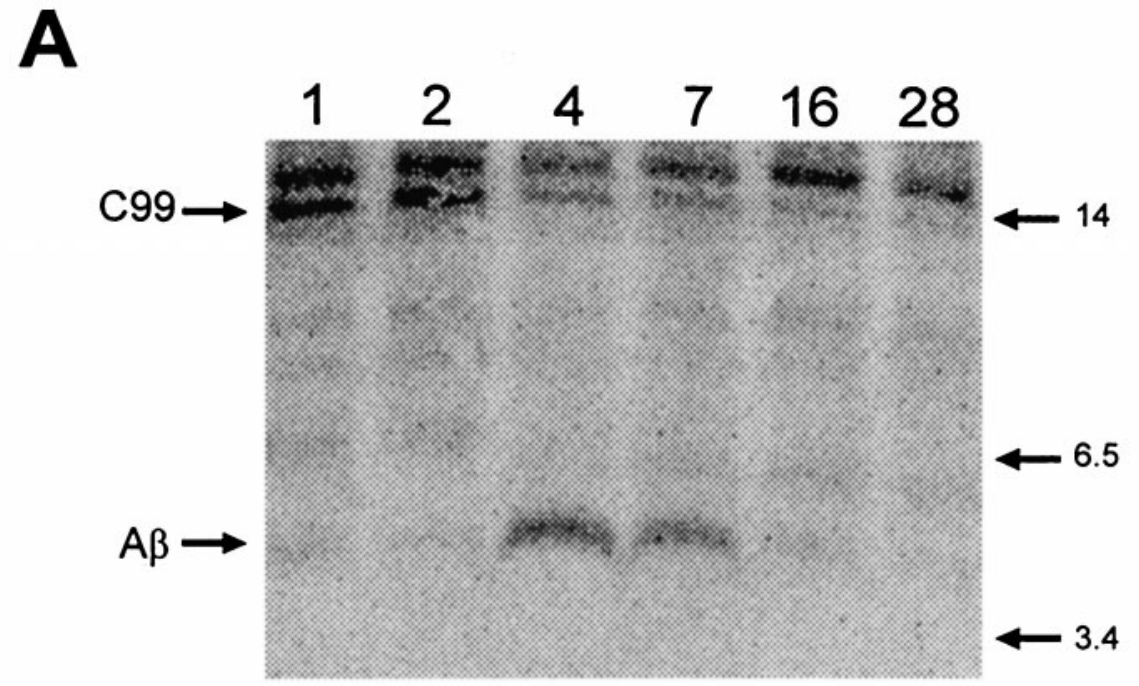

B
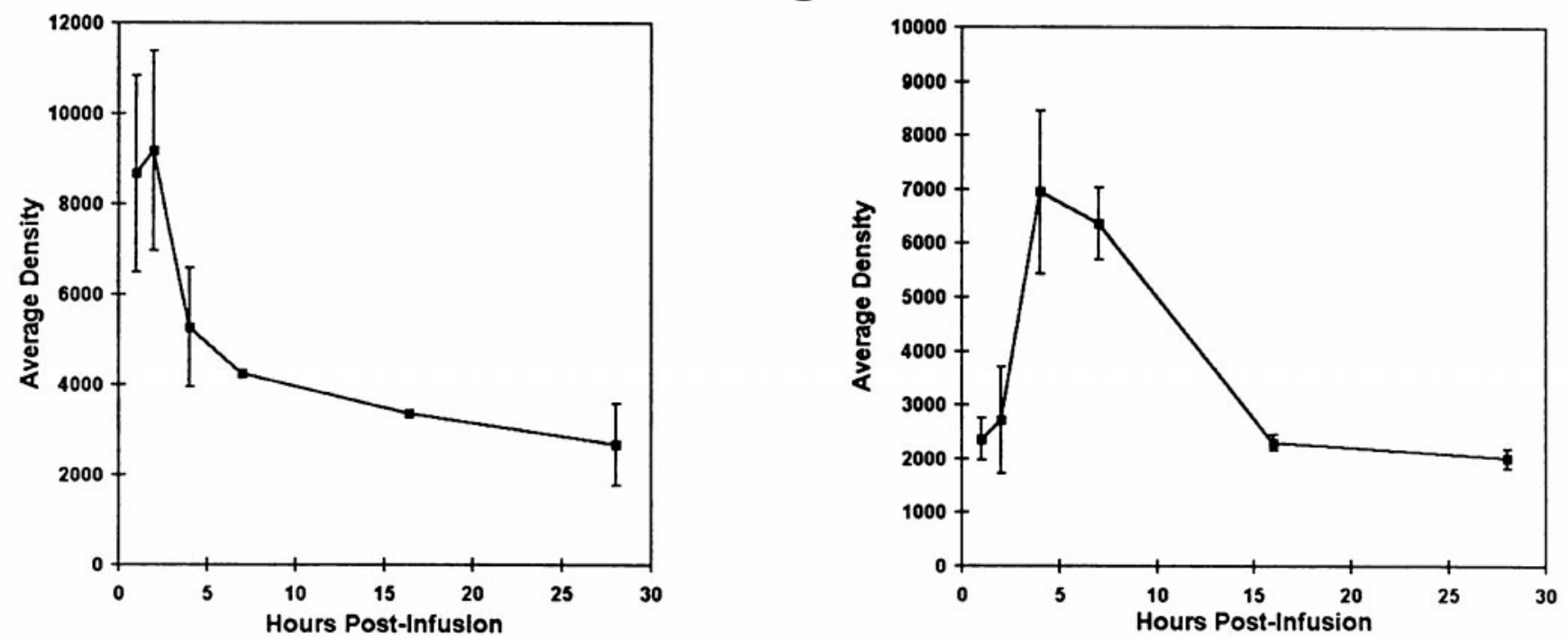

D

E

$\begin{array}{llllll}1 & 2 & 4 & 7 & 16 & 28\end{array}$

$\begin{array}{llllll}1 & 2 & 4 & 7 & 16 & 28\end{array}$
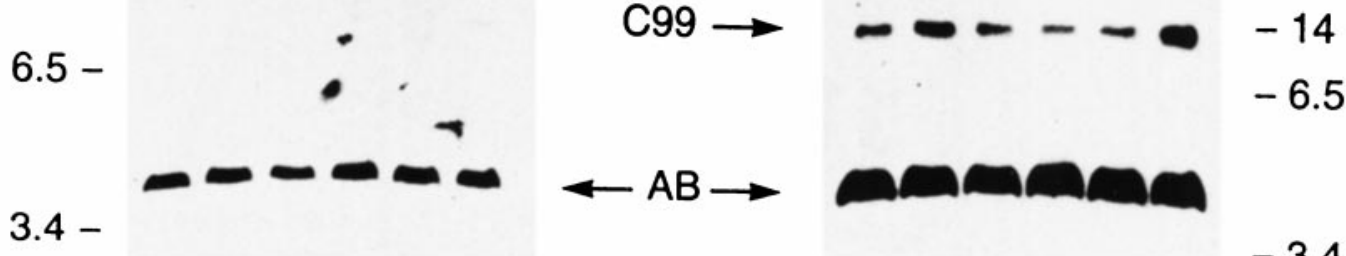

$-3.4$

Figure 1. Time-dependent changes in specific activity of mouse brain $\mathrm{A} \beta$ and $\mathrm{C} 99 .\left[{ }^{35} \mathrm{~S}\right]$ Methionine $(500 \mu \mathrm{Ci})$ was infused into the femoral vein of gene-targeted mice. At indicated hourly time points after midpoint of inf usion, mice were perfused with Ringer's solution, and brain APP fragments were isolated by immunoprecipitation and visualized using electrophoresis and exposure of resolved proteins to phosphorimage screens. $A$, Representative phosphorimage showing radiolabeled $\mathrm{A} \beta$ and $\mathrm{C} 99$. Graphs illustrating change in density of $\mathrm{C} 99(B)$ or $\mathrm{A} \beta(C)$ with time are shown. $n=3$ at each time point. $D, E$, Representative immunoblots confirming equivalent absolute levels of $\mathrm{A} \beta$ and $\mathrm{C} 99$ during these experiments. Immobilized proteins used to obtain the phosphorimage in $A$ were detected using antibody 6E10. $D, \mathrm{~A} \beta ; E, \mathrm{C} 99$ and $\mathrm{A} \beta$ (from a longer exposure of $D$ ). 


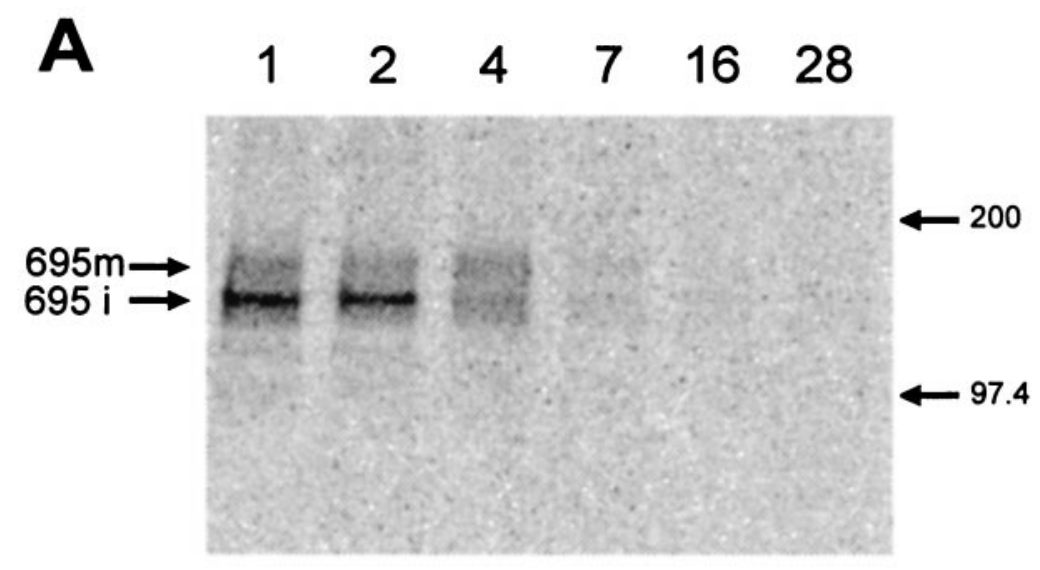

B

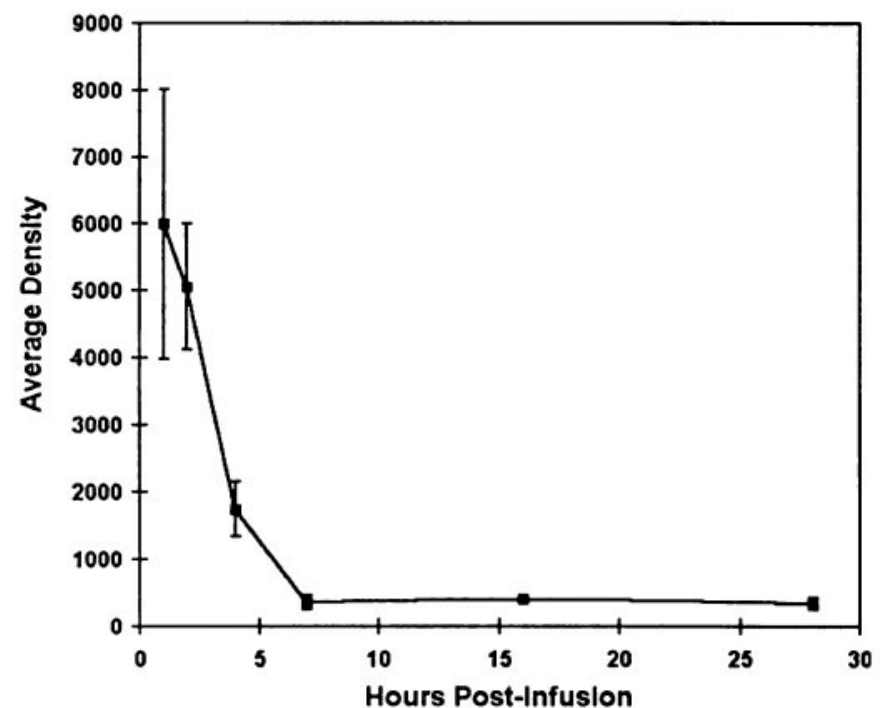

D

\section{C}

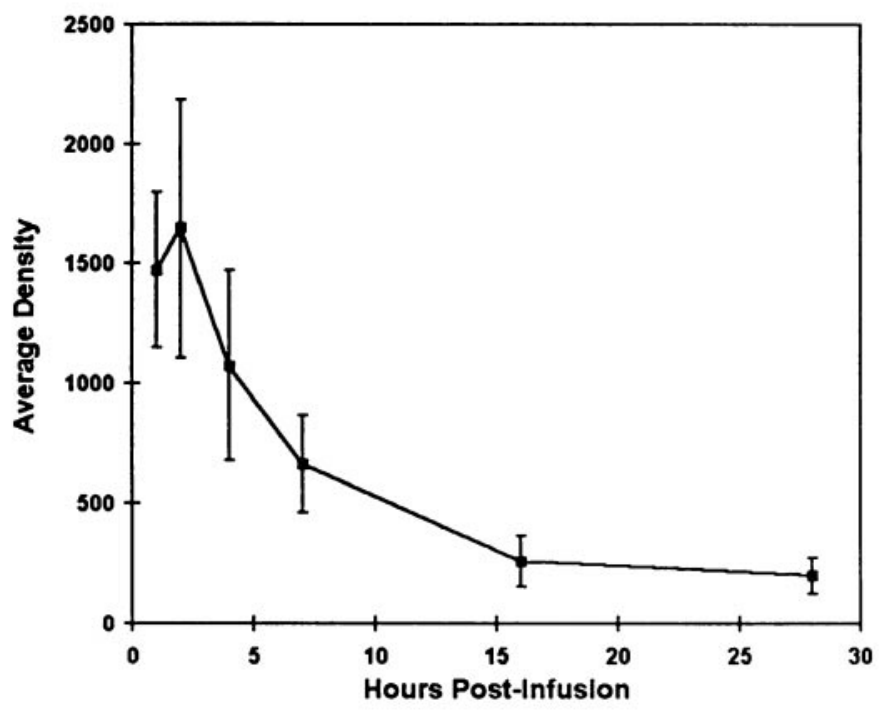

E

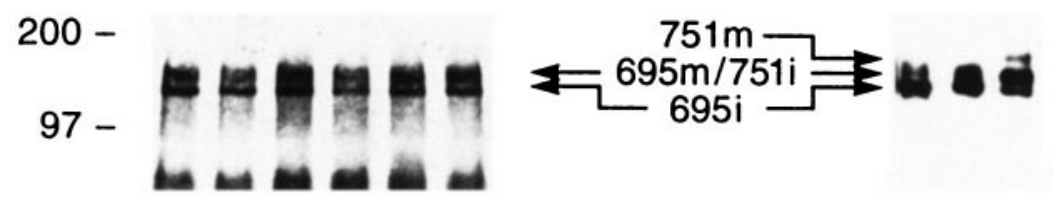

Figure 2. Change in specific activity of mouse brain APP with time. Mice were treated as reported in the legend to Figure 1 and Materials and Methods. $A$, Representative phosphorimage showing radiolabeled immature $(i)$ and fully glycosylated $(m)$ APP 695 . $B$, $C$, Time-dependent change in specific activity of immature $(B)$ and fully glycosylated APP695 $(C) . n=3$ at each time point. $D$, Representative Western blot showing relatively constant absolute levels of APP, although specific activity was changing. E. Immunoblot confirming the predominant forms of APP synthesized by gene-targeted mouse. The most prominent band in the gene-targeted mouse brain sample (lane 2) co-electrophoreses with immature human APP695 from transgenic rat brain (lane 1) and lowest APP form isolated from human cortex (lane 3). The top band in the full-length APP complex (lane 2) co-electrophoreses with fully glycosylated human APP 695 from transgenic rat (lane 1).

by molecular weight and reactivity with two $\mathrm{A} \beta / \mathrm{APP}$-specific antibodies (1153 and 6E10), one of which is specific for human APP and derivatives (6E10). Radiolabeled proteins immunoprecipitated with 1153 migrated between 3.5 and $6 \mathrm{kDa}($ Fig. $1 \mathrm{~A}$ ), at
$14 \mathrm{kDa}$ (Fig. $1 A$ ), or between 97 and $200 \mathrm{kDa}$ (Fig. 2A) and aligned precisely with proteins immunodetected with 6 E10 (Figs. $1 D, E, 2 D)$. These proteins are, therefore, identified as $\mathrm{A} \beta, \mathrm{C} 99$, and APP, respectively. All three immunoblotted proteins also 
A
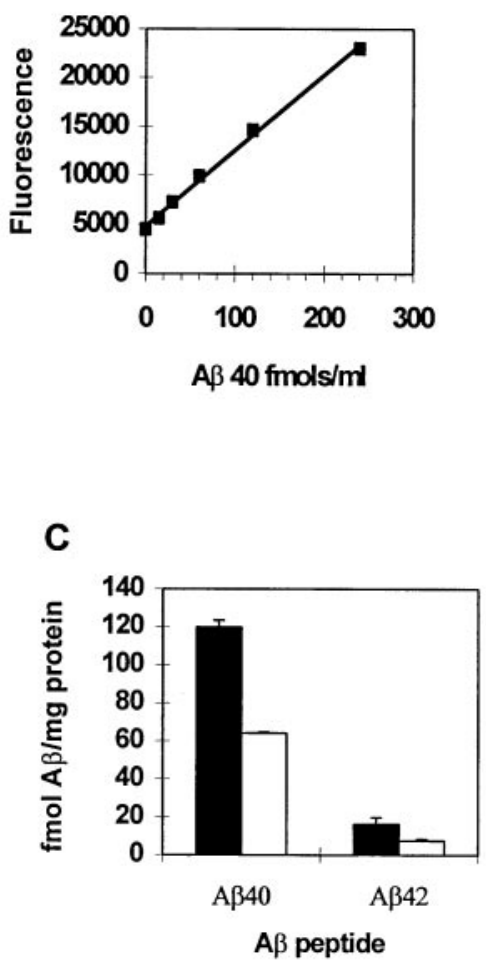

B

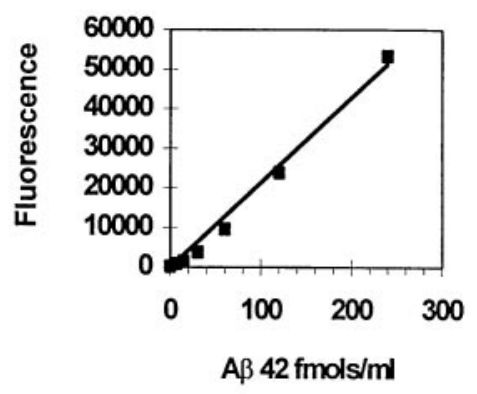

D

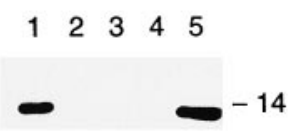

Figure 3. ELISAs selective for $\mathrm{A} \beta 40$ and $\mathrm{A} \beta 42$ detect levels of endogenous $\mathrm{A} \beta$, correctly reflecting gene dosage. $A$, Standard curve of $\mathrm{A} \beta 1-40$ generated using ELISA with a polyclonal antibody selective for $\mathrm{A} \beta 40$. $B$, Standard curve of $\mathrm{A} \beta 1-42$ using 42 -selective ELISA. $C$, Soluble A $\beta$ extracted from brains of gene-targeted mice having one copy (white bars) or two copies (black bars) of the targeted allele. $n=3$ in each group. $D$, Immunoblot showing that the DEA extraction method does not release detectable levels of C99, an abundant, membranespanning form of APP. Lanes 2-4, Extracts immunoprecipitated with antibody 97, which recognizes the $\mathrm{C}$ terminus of C99; lane 1, recombinant $\mathrm{C} 100$ added into DEA extract before immunoprecipitation; lane 5, $0.5 \mathrm{ng}$ of $\mathrm{C} 100$ loaded directly on to the gel. co-electrophoresed with APP-related standards (APP, Fig. 2E; $\mathrm{A} \beta$ and $\mathrm{C} 99$, data not shown).

C99 achieved its maximal observed specific activity between 1 and $2 \mathrm{hr}$ after inf usion (Fig. $1 A$ ). The $t_{1 / 2}$ estimate based on decay of C99 signal over time was $\sim 3$ hr (Fig. $1 B$ ). Peak specific activity of the A $\beta$ peptide was achieved by $4-7 \mathrm{hr}$ after infusion with the signal returning to baseline levels by $16 \mathrm{hr}$ (Fig. $1 A, C$ ). Because there were no data points on the downward slope of the $\mathrm{A} \beta$ decay curve, an approximate $t_{1 / 2}$ for $\mathrm{A} \beta$ is best estimated from its rate of formation, because, at steady-state, the rate of protein synthesis equals the rate of turnover. The specific activity of the $\mathrm{A} \beta$ protein increased from background at $2 \mathrm{hr}$ after infusion to peak incorporation between 4 and $7 \mathrm{hr}$ (i.e., 2-5 hr later). Therefore, we estimate the $t_{1 / 2}$ to be between 1.0 and $2.5 \mathrm{hr}$. The coincident decay of $\mathrm{C} 99$ and formation of $\mathrm{A} \beta$ in vivo supports the precursorproduct relationship of these two APP derivatives, respectively (Golde et al., 1992; Cai et al., 1993; Perez et al., 1996). To determine absolute levels of these fragments during the course of the experiment, and also to confirm their identities, immunoblotting was performed using $6 \mathrm{E} 10$ (Fig. $1 D, E$ ). Absolute levels of $\mathrm{A} \beta$ and $C 99$ were relatively constant at each time point, whereas their specific activities were changing. This confirms that the turnover measurements were performed under steady-state conditions. A radiolabeled protein that migrated slightly slower than C99 (Fig. $1 A$ ) was not labeled with $6 \mathrm{E} 10$ (Fig. $1 E$ ). This protein, therefore, was not derived from APP and was nonspecifically precipitated.

Full-length APP was immunoprecipitated using the Cterminal-specific Ab 97. Two major proteins were evident on both the phosphorimage (Fig. 2A) and immunoblot with 6E10 (Fig. $2 D)$. On both images, the lower $M_{\mathrm{r}}$ band was sharply focused, and the upper band was more diffuse, as is typically seen with mature, fully glycosylated APPs (e.g., Oltersdorf et al., 1990). Most of the APP made in the brains of our gene-targeted mice (Fig. 2E) is
APP695, as expected for rodent brain (Rockenstein et al., 1995). The major proteins immunoprecipitated with Ab 97 and immunodetected with 6E10 electrophoresed precisely with both of the major APP forms extracted from the brain of a transgenic rat overexpressing human APP695. In addition, the lowest $M_{\mathrm{r}}$ band detected in the gene-targeted brains co-electrophoresed with the lowest band isolated from human cortex, which is immature APP695. APP-like proteins (APLPs) are also present in mouse brain (Wasco et al., 1992) and could contribute to the phosphorimage signals. This is unlikely, because proteins seen on the Western blot using 6E10 (which does not recognize APLPs) precisely co-electrophorese with the radiolabeled proteins immunoprecipitated with Ab97.

Immature APP695 attained its peak specific activity by $1 \mathrm{hr}$ (Fig. $2 B$ ), and the $t_{1 / 2}$ of this material appeared to be $\sim 3 \mathrm{hr}$. The specific activity of mature APP695 peaked between 1 and $2 \mathrm{hr}$ and fell to background by $16 \mathrm{hr}$ (Fig. 2C). Therefore, the $t_{1 / 2}$ was $\sim 7 \mathrm{hr}$.

\section{ELISAs detect $A \beta 40$ and $A \beta 42$ in brains of gene-targeted mice}

Using sandwich ELISAs selective for $\mathrm{A} \beta$ peptides with $\mathrm{C}$ termini ending at residue 40 or $42, \mathrm{~A} \beta$ was detected in brain extracts. The 40 -selective assay (Fig. $3 A$ ) was linear to $240 \mathrm{fmol} / \mathrm{ml}$ and sensitive to $12 \mathrm{fmol} / \mathrm{ml}$. This assay was $>1000-, 5000-$, or 10,000 -fold more selective for $\mathrm{A} \beta 1-40$ compared with $\mathrm{A} \beta 1-43, \mathrm{C} 100$, or A $\beta 1-42$ standards, respectively. Brain $A \beta 40$ levels measured in the homozygous, gene-targeted mouse brain with this ELISA are $120 \mathrm{fmol} / \mathrm{mg}$ protein.

The 42-selective assay (Fig. $3 B$ ) was linear to $480 \mathrm{fmol} / \mathrm{ml}$ and sensitive to $7.4 \mathrm{fmol} / \mathrm{ml}$. This assay was $400-, 10,000-$, or $16,000-$ fold more selective for $A \beta 1-42$ compared with $A \beta 1-43, A \beta 1-40$, or $\mathrm{C} 100$ standards, respectively. Selectivity in the A $\beta 42$ ELISA 


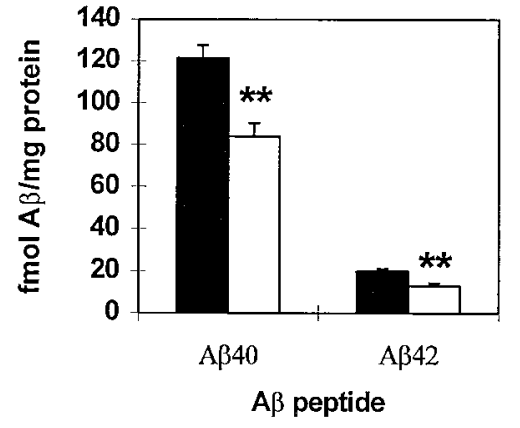

Figure 4. Effect of PMA on levels of $\mathrm{A} \beta 40$ and $\mathrm{A} \beta 42 . \mathrm{A} \beta$ proteins were significantly reduced $6 \mathrm{hr}$ after treatment. PMA was injected into the parietal cortex of the gene-targeted mouse. Parietal cortex was removed, and $\mathrm{A} \beta$ was extracted using DEA-NaCl buffer, neutralized to $\mathrm{pH} 8.0$, and analyzed by ELISA; vehicle values are in black, and PMA values are in white. $\mathrm{A} \beta 40$ and $\mathrm{A} \beta 42$ were reduced by $31(p<0.0001)$ and $35 \%(p<$ $0.0001)$, respectively. Number of animals per group: 40 assay, vehicle, 30 ; PMA, 39; 42 assay, vehicle, 24; PMA, 33.

resided in the detecting antibody, unlike the 40-specific ELISA. Because the DEA extracts contain little membrane-associated C99 (Fig. 3D) or APP (data not shown), the nonselective 6E10 capture reagent was not saturated by C99 or full-length APP and was therefore free to capture DEA-extracted A $\beta$ species. Wholebrain $\mathrm{A} \beta 42$ levels measured using this ELISA are $16 \mathrm{fmol} / \mathrm{mg}$ protein. Both ELISAs also responded appropriately to twofold differences in brain $\mathrm{A} \beta$ driven by gene dosage. Extracts from homozygous mice revealed a twofold higher signal in the ELISA compared with heterozygous mice with only one copy of the targeted allele (Fig. 3C), confirming a previous observation made using Western blotting (Reaume et al., 1996).

\section{Phorbol ester reduces cortical A $\beta$ and APP $\beta$ levels acutely}

Because the $\mathrm{A} \beta$ protein is cleared within a few hours of its synthesis in the mouse brain, we examined the acute effect of the phorbol ester PMA on the level of $\mathrm{A} \beta$ and other APP derivatives. Highly significant $30-35 \%$ reductions in levels of $A \beta 40$ (from 121.4 to $84.1 \mathrm{fmol} / \mathrm{mg}$ ) and $\mathrm{A} \beta 42$ (from 20 to $12.9 \mathrm{fmol} / \mathrm{mg}$ ) were seen in parietal cortex $6 \mathrm{hr}$ after intracortical injection of $40 \mathrm{nmol}$ of PMA (Fig. $4 ; p<0.0001$ ). By 12 hr, the effect on A $\beta 40$ was lost (Fig. $5 A$ ). A $\beta 42$ levels were not examined at $12 \mathrm{hr}$. Intracortical injection of $40 \mathrm{nmol}$ of $4 \alpha \mathrm{PMA}$, an analog of PMA unable to activate PKC (Castagna et al., 1982; Kikkawa et al., 1983; Nichols et al., 1987), failed to reduce $A \beta 40$ levels at 40 nmol $6 \mathrm{hr}$ after injection (Fig. $5 B$ ). The hippocampus was also examined and was inconsistently affected by PMA injection (data not shown). It is possible that this highly lipophilic compound did not travel a significant distance from the injection site.

$\operatorname{APP} \alpha$ and APP $\beta$ levels were also examined $6 \mathrm{hr}$ after PMA injection from the same extracts used to measure $A \beta$. In contrast to expectations from cell culture experiments, APP $\alpha$ levels were unchanged by this compound (Fig. 6A). APP $\beta$ levels, on the other hand, were significantly reduced by $32 \%$ in the PMA-treated group $(p<0.02)$ (Fig. $6 B)$. The degree of difference in levels of the two forms of secreted APP compared with controls was essentially identical whether the values were normalized to the actin band subsequently visualized within each blotted sample.

\section{DISCUSSION}

We examined the synthesis and turnover of human $\mathrm{A} \beta$ present within the gene-targeted mouse brain and used this information
A

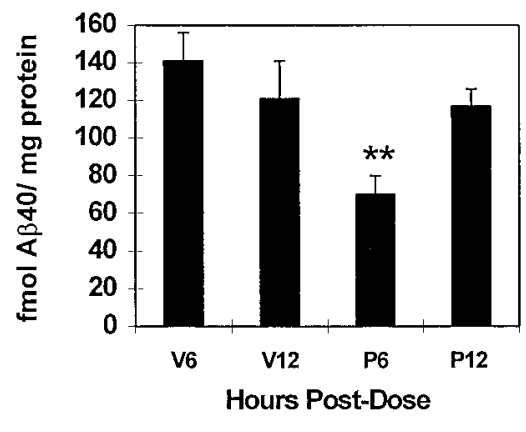

B

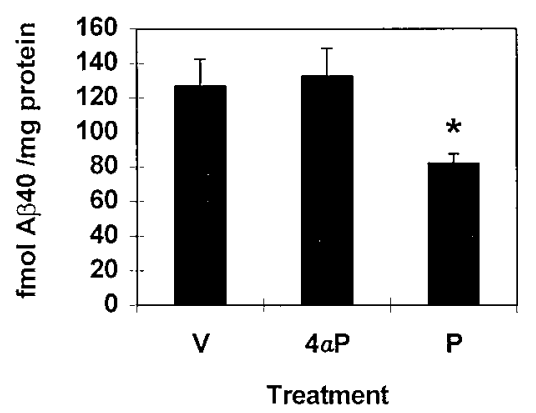

Figure 5. Time-dependent reduction in $\mathrm{A} \beta$ levels after PMA treatment. A $\beta$ levels were unaffected by $4 \alpha$ PMA. $A$, Significant reductions in A $\beta 40$ at $6 \mathrm{hr}(P 6, p<0.001)$ were gone by $12 \mathrm{hr}(P 12)$. V, Vehicle; $P$, PMA. Number of animals per group: V6, 6; V12, 6; P6, 11; P12, 12. B, $4 \alpha \mathrm{PMA}$ $(4 \alpha P)$ did not lower cortical A $\beta 40$ levels after $6 \mathrm{hr}$ compared with the active analog PMA $(P, p<0.03)$. Number of animals per group: $V, 6 ; 4 \alpha P$, 7; $P, 6$.

to design studies aimed at the reduction of brain $\mathrm{A} \beta$. Under the control of the mouse APP promoter, this model provided appropriate cellular production of human $\mathrm{A} \beta$ and allowed the study of A $\beta$ and APP metabolism under physiologically relevant APP concentrations. A $\beta, \mathrm{C} 99$, and APP undergo virtually complete clearance within $1 \mathrm{~d}$ in this model. The estimated $t_{1 / 2}$ for $\mathrm{A} \beta$ is between 1.0 and $2.5 \mathrm{hr}$ and was estimated from the rate of synthesis, because, at steady-state levels of protein, the rate of synthesis equals the rate of turnover. In addition to metabolic turnover of $\mathrm{A} \beta$, rapid transport of this protein out of the brain into either blood or CSF could also contribute to its clearance. Although $\mathrm{A} \beta$ transport into brain across the blood-brain barrier has been reported (Zlokovic et al., 1993), transport of $\mathrm{A} \beta$ out of brain parenchyma has not yet been demonstrated.

Western blot data show steady-state levels of all APP-related proteins over the course of the experiment. The $t^{1 / 2}$ values predicted here for immature APP (3 hr), fully glycosylated APP (7 hr), and C99 (3 hr) were based on turnover of those molecules that acquired $\left[\mathrm{S}^{35}\right]$ methionine during the original pulse and via reuse of label released from rapidly metabolized proteins. Rates of synthesis for C99 and APP could not be used to obtain more precise estimates of $t_{1 / 2}$, because the specific activity of both forms of APP and C99 had already peaked at the earliest time examined. A more precise definition of the half-lives of these proteins based on the rate of synthesis in vivo would require a shorter 

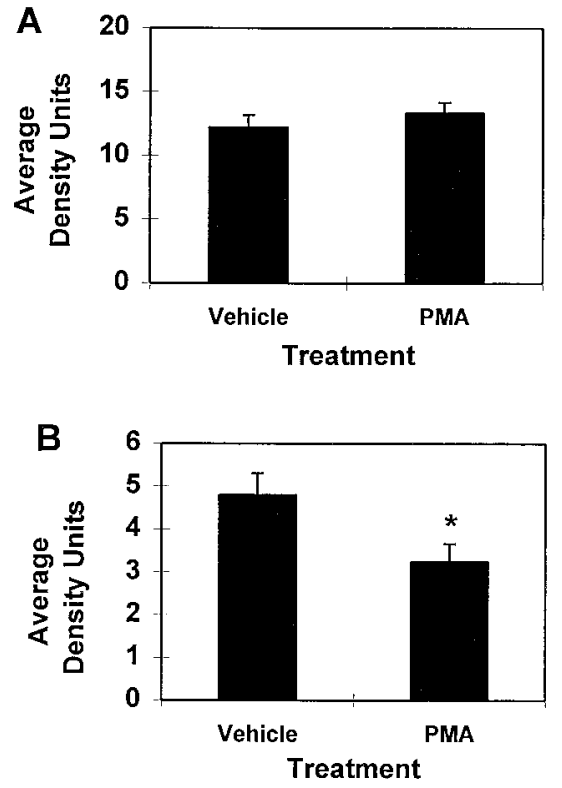

Figure 6. Effect of PMA on levels of $\mathrm{APP} \alpha$ and $\mathrm{APP} \beta$ in parietal cortex $6 \mathrm{hr}$ after treatment. Cortical APP $\beta$ levels were significantly reduced by PMA treatment, whereas APP $\alpha$ levels are unchanged. These APP fragments were assayed from the DEA extracts used to measure A $\beta$. Equivalent amounts of protein were $\mathrm{MeOH}$-precipitated and immunoblotted with either $6 \mathrm{E} 10(A)$ to visualize $\mathrm{APP} \alpha$ or $54(B)$ to visualize $\mathrm{APP} \beta$. The reduction of APP $\beta$ is significant to $p<0.02$. Number of animals per group: vehicle, 19; PMA, 23.

pulse duration and the measurement of points between time 0 and $1 \mathrm{hr}$.

We have shown that peripheral infusion of $\left[{ }^{35} \mathrm{~S}\right]$ methionine over $30 \mathrm{~min}$ is sufficient to visualize $\mathrm{A} \beta$ and its precursors in mouse brain, despite the presence of only one methionine per $\mathrm{A} \beta$ molecule, and a background of physiological levels of unlabeled methionine. In studies that examined turnover of total protein in brain using TCA precipitation, there was concern that a stable pool of radiolabeled precursor be maintained to act as a saturating pulse (Garlick and Marshall, 1972; Dunlop et al., 1975; Reith et al., 1978). In these experiments, very long infusion periods or large bolus injections of radiolabel were delivered to saturate the precursor pools. Continuous infusion of $\left[{ }^{35} \mathrm{~S}\right]$ methionine and other radiolabeled amino acids directly into small subregions of the brain has also been used to study the synthesis and transport of substance P (Sperk and Singer, 1982; Torrens et al., 1982; Krause et al., 1984) and other neuropeptides (Kochman et al., 1982; Krause et al., 1982). This report demonstrates whole-brain synthesis and degradation of specific proteins using peripheral infusion of radiolabeled amino acid over a relatively short inf usion interval.

The synthesis and turnover of APP and APP fragments have been studied extensively in vitro (Weidemann et al., 1989; Oltersdorf et al., 1990; Haass et al., 1991; Golde et al., 1992; Busciglio et al., 1993; Siman et al., 1993; Perez et al., 1996). Pulse-chase experiments using $\left[{ }^{35} \mathrm{~S}\right]$ methionine showed processing of APP to fully glycosylated, proteolytically cleaved forms within $1 \mathrm{hr}$ in non-neuronal cells (Oltersdorf et al., 1990; Haass et al., 1991; Golde et al., 1992; Busciglio et al., 1993; Siman et al., 1993). In contrast, the half-life of immature APP was $3 \mathrm{hr}$ in the neuronal NT2N cell line (Wertkin et al., 1993), identical to the half-life we estimate in vivo. The gene-targeted mice have the
Swedish FAD mutation within the context of mouse APP, unlike the wild-type, human APP present in NT2N cells. When turnover rates of wild-type versus Swedish mutant APP have been compared in vitro, they were found to be identical (Perez et al., 1996). Therefore, the turnover rate estimate of the APP present in the gene-targeted mice likely reflects the in vivo turnover of wild-type APP as well.

The turnover of $\mathrm{C}$-terminal derivatives measured in various cell culture systems has ranged from 1-2 hr to $>8 \mathrm{hr}$ (Oltersdorf et al., 1990; Haass et al., 1991; Estus et al., 1992; Busciglio et al., 1993; Siman et al., 1993; Martin et al., 1995). Our estimate of the $t_{1 / 2}$ of C99 in vivo from expression of the Swedish mutant transgene falls within that range. The cellular compartment in which $\beta$-secretase activity generates the $N$ terminus of $\mathrm{A} \beta$ differs for APPs containing the Swedish FAD mutation compared with wild-type forms (Haass et al., 1995; Thinakaran et al., 1996). A $13.5 \mathrm{kDa}$ fragment (analogous to $\mathrm{C} 99$ here) appeared more rapidly in mouse N2a cells transfected with Swedish mutant APP than wild-type APP (Thinakaran et al., 1996). Therefore, the rate of formation of C99 may also be more rapid in our gene-targeted mouse system expressing Swedish mutant APP compared with wild-type APP.

$\mathrm{A} \beta$ turnover in vitro has been studied recently (Naidu et al., 1995; Qiu et al., 1996, 1997). The peak specific activity of radiolabeled $\mathrm{A} \beta$ secreted from Chinese hamster ovary ( $\mathrm{CHO}$ ) cells transfected to overexpress APP 695 occurred at $6 \mathrm{hr}$ (Naidu et al., 1995), similar to the result in our gene-targeted system. Estimates of $\mathrm{A} \beta t_{1 / 2}$ values are also comparable between 1.5 and $3 \mathrm{hr}$. Similar rates of $\mathrm{A} \beta$ secretion have been found using $\mathrm{CHO}$ cells expressing either wild-type or Swedish mutant forms of APP, whereas the amount of $\mathrm{A} \beta$ secreted was elevated in the presence of the mutation (Perez et al., 1996). We predict that turnover rates of $A \beta$ determined in this study will estimate the rates for $\mathrm{A} \beta$ generated from wild-type APP if the compartments in which $\mathrm{A} \beta$ is metabolized are the same, and $A \beta$ turnover mechanisms are not saturated.

Specific proteases that metabolize $\mathrm{A} \beta$ are beginning to be identified. A serine protease $-\alpha_{2}$-macroglobulin complex was identified in preparations of pancreatic trypsin or fetal bovine serum that degraded exogenous $\mathrm{A} \beta$, as well as $\mathrm{A} \beta$ secreted by cells (Qiu et al., 1996). A nonmatrix metalloprotease and a serine protease secreted by both $\mathrm{CHO}$ cells and BV-2 microglial cells have also been reported to catabolize A $\beta$ (Qiu et al., 1997). Microglial cells in brain may, therefore, secrete a protease important for $\mathrm{A} \beta$ turnover in vivo. Turnover of $\mathrm{A} \beta$ could also occur in an intracellular compartment, because $\mathrm{A} \beta_{42}$ uptake from extracellular medium has been described (Knauer et al., 1992); also, the de novo synthesis of intracellular $\mathrm{A} \beta$ has been reported in primary neurons (Tienari et al., 1997), NT2N cells (Wertkin et al., 1993), and 293 or CHO cells transfected with Swedish mutant APP (Martin et al., 1995, Perez et al., 1996). Rates of A $\beta$ synthesis and clearance determine its steady-state level and dysfunction of either process could lead to the elevation of $\mathrm{A} \beta$ to concentrations critical for fibril formation.

Using this information concerning the turnover rate of $\mathrm{A} \beta$ in mouse brain, we investigated the effects of intracortically injected phorbol esters on brain $\mathrm{A} \beta$ metabolism. The development of these gene-targeted mice was critical to our study because $A \beta$ is undetectable in wild-type mouse brain with either our ELISA or immunoblotting methods. A highly significant $30-35 \%$ reduction was demonstrated in levels of both $A \beta 40$ and $A \beta 426 \mathrm{hr}$ after administration of PMA. Six hours was chosen as the earliest 
postdose interval after PMA, allowing 2-6 half-lives for $\mathrm{A} \beta$ clearance. This is the first report of the selective effects of PMA on $A \beta 40$ and $A \beta 42$ as measured by ELISA. For the elevation of PKC activity to be considered a therapeutically relevent approach for the treatment of $\mathrm{AD}$, it was necessary to demonstrate reduction in levels of brain $A \beta 42$ with a compound known to impact this pathway. The selective effect of phorbol ester stimulation on $\mathrm{A} \beta 42$ was examined previously using an in vitro system, whereas $\mathrm{A} \beta 40$ was measured as part of the "total" $\mathrm{A} \beta$ that remained (Citron et al., 1996). In our study, cortical levels of $A \beta 40$ returned to baseline by $12 \mathrm{hr}$, possibly reflecting the half-life of PMA in mouse brain, which was determined to be $9.6 \mathrm{hr}$ (Dietrich et al., 1989). We expect the $A \beta 42$ followed a similar time course of recovery, although this fragment was not measured at $12 \mathrm{hr}$.

The activity of PMA on APP processing in mouse brain is presumably through its selective PKC-stimulatory function (Newton, 1995; Nishizuka, 1995), because an analog that is unable to activate PKC, $4 \alpha$-PMA, had no effect on A $\beta$ levels. We were unable to measure changes in PKC translocation after PMA delivery in mouse brain, because the DEA extraction buffer led to the release of membrane-associated PKC (data not shown). Therefore, it was not possible to measure concomitant effects of PMA on $\mathrm{A} \beta$ levels and PKC activity.

The role of PKC in modulating APP processing was determined by the discovery that stimulation of $\mathrm{PKC}$ either directly (Caporaso et al., 1992) or by activation of muscarinic receptor subtypes linked to this second messenger pathway (Buxbaum et al., 1992; Nitsch et al., 1992; Farber et al., 1995), led to an increase in the secretion of APP $\alpha$ and concomitant reduction in both $\mathrm{A} \beta$ (Buxbaum et al., 1993; Hung et al., 1993) and APP $\beta$ (Felsenstein et al., 1994; Jacobsen et al., 1994). These results suggested either increased processing of APP via an $\alpha$-secretase-mediated pathway (by increased secretase activity or a rerouting of full-length APP to compartments involved in $\alpha$-secretase processing) or decreased activity via a $\beta$-secretase-mediated pathway. We chose to study the effect of a phorbol ester in vivo, because PKC itself is ubiquitously expressed, whereas select cell surface receptors linked to PKC have a more focal distribution.

In contrast to $\mathrm{A} \beta, \mathrm{APP} \alpha$ levels were unchanged $6 \mathrm{hr}$ after PMA delivery, whereas APP $\beta$ levels decreased significantly. This correlation of $\mathrm{A} \beta$ reduction with $\mathrm{APP} \beta$ reduction suggests that there is reduced cleavage of APP by $\beta$-secretase in the presence of phorbol esters, as suggested previously (Buxbaum et al., 1993; Hung et al., 1993; Felsenstein et al., 1994; Jacobsen et al., 1994). The lack of significant elevation in levels of $\operatorname{APP} \alpha$ after phorbol ester treatment in vivo could be attributed to more efficient turnover of this protein compared with in vitro systems or, alternatively, to a dissociation of systems regulating $\mathrm{A} \beta / \mathrm{APP} \beta$ secretion and $\operatorname{APP} \alpha$ secretion in the mouse brain. These processes have been reported to be dissociated in certain in vitro systems (Gabuzda et al., 1993; Dyrks et al., 1994; Fuller et al., 1995). Recently, however, increased APP $\alpha$ secretion was reported in a rat model in which PKC activity was constitutively upregulated after treatment with menthylazoxymethanol in utero (Caputi et al., 1997), supporting the influence of this pathway on APP processing in vivo. Together, these studies emphasize the importance of measuring all APP fragments of interest when testing pharmacological modulators of APP processing in brain. In drug discovery efforts, for example, the degree to which a compound is effective in lowering $\mathrm{A} \beta$ levels should not be based exclusively on the measurement of a surrogate marker, such as $\operatorname{APP} \alpha$. In addition, test systems must effectively model both synthesis and clear- ance of brain $\mathrm{A} \beta$ and other APP-processing fragments; cultured cells may only partially represent these processes.

Collectively, our data show that the gene-targeted mouse is a useful model for the study of agents that modulate $\mathrm{A} \beta$ levels in brain. Turnover of brain $\mathrm{A} \beta$ protein under physiological conditions occurs within several hours. This makes possible the design of further studies to investigate agents that modulate $\mathrm{A} \beta$ levels in vivo whether by modulation of $\mathrm{PKC}$ activity or by alternative pathways independent of PKC.

\section{REFERENCES}

Baranyi A, Szente MB, Woody CD (1987) Intracellular injection of phorbol ester increases the excitability of neurons of the motor cortex of awake cats. Brain Res 424:396-401.

Busciglio J, Gabuzda DH, Matsudaira P, Yankner BA (1993) Generation of $\beta$-amyloid in the secretory pathway in neuronal and nonneuronal cells. Proc Natl Acad Sci USA 90:2092-2096.

Buxbaum JD, Oishi M, Chen HI, Pinkas-Kramarski R, Jaffe EA, Gandy SE, Greengard P (1992) Cholinergic agonists and interleukin 1 regulate processing and secretion of the Alzheimer $\beta / \mathrm{A} 4$ amyloid protein precursor. Proc Natl Acad Sci USA 89:10075-10078.

Buxbaum JD, Koo EH, Greengard P (1993) Protein phosphorylation inhibits production of Alzheimer amyloid $\beta / \mathrm{A} 4$ peptide. Proc Natl Acad Sci USA 90:9195-9198.

Cai XD, Golde TE, Younkin SG (1993) Release of excess amyloid $\beta$ protein from a mutant amyloid $\beta$ protein precursor. Science 259: 514-516.

Caporaso GL, Gandy SE, Buxbaum JD, Ramabhadran TV, Greengard P (1992) Protein phosphorylation regulates secretion of Alzheimer $\beta /$ A4 amyloid protein precursor. Proc Natl Acad Sci USA 89:3055-3059.

Caputi A, Barindelli S, Pastorino L, Cimino M, Buxbaum JD, Cattabeni F, Di Luca M (1997) Increased secretion of the amino-terminal fragment of amyloid precursor protein in brains of rats with a constitutive upregulation of protein kinase C. J Neurochem 68:2523-2529.

Castagna M, Takai Y, Kaibuchi K, Sano K, Kikkawa U, Nishizuka Y (1982) Direct activation of calcium-activated, phospholipid-dependent protein kinase by tumor-promoting phorbol esters. J Biol Chem 257:7847-7851.

Citron M, Oltersdorf T, Haass C, McConlogue L, Hung AY, Seubert P, Vigo-Pelfrey C, Lieberburg I, Selkoe DJ (1992) Mutation of the $\beta$-amyloid precursor protein in familial Alzheimer's disease increases $\beta$-protein production. Nature 360:672-674.

Citron M, Vigo-Pelfrey C, Teplow DB, Miller C, Schenk D, Johnston J, Winblad B, Venizelos N, Lannfelt L, Selkoe DJ (1994) Excessive production of amyloid $\beta$-protein by peripheral cells of symptomatic and presymptomatic patients carrying the Swedish familial Alzheimer disease mutation. Proc Natl Acad Sci USA 91:11993-11997.

Citron M, Diehl TS, Gordon G, Biere AL, Seubert P, Selkoe DJ (1996) Evidence that the 42 - and 40 -amino acid forms of amyloid $\beta$ protein are generated from the $\beta$-amyloid precursor protein by different protease activities. Proc Natl Acad Sci USA 93:13170-13175.

Cope FO, Conrad EA, Staller JM, Boutwell RK (1984) Induction of mouse brain ornithine decarboxylase by $12-O$-tetradecanoylphorbol-13acetate is independent of TPA receptor concentration. Cancer Lett 23:331-342.

Deitrich RA, Bludeau PA, Baker RC (1989) Investigations of the role of protein kinase $\mathrm{C}$ in the acute sedative effects of ethanol. Alcohol Clin Exp Res 13:737-745.

Dunlop DS, van Elden W, Lajtha A (1975) A method for measuring brain protein synthesis rates in young and adult rats. J Neurochem 24:337-344.

Dyrks T, Mönning U, Beyreuther K, Turner J (1994) Amyloid protein precursor secretion and $\beta \mathrm{A} 4$ amyloid generation are not mutually exclusive. FEBS Lett 349:210-214

Estus S, Golde TE, Kunishita T, Blades D, Lowery D, Eisen M, Usiak M, Qu X, Tabira T, Greenberg BD, Younkin SG (1992) Potentially amyloidogenic, carboxyl-terminal derivatives of the amyloid protein precursor. Science 255:726-728.

Farber SA, Nitsch RM, Schulz JG, Wurtman RJ (1995) Regulated secretion of $\beta$-amyloid precursor protein in rat brain. J Neurosci 15:7442-7451.

Felsenstein KM, Ingalls KM, Hunihan LW, Roberts SB (1994) Reversal of the Swedish familial Alzheimer's disease mutant phenotype in 
cultured cells treated with phorbol 12, 13-dibutyrate. Neurosci Lett 174:173-176.

Fuller SJ, Storey E, Li QX, Smith AI, Beyreuther K, Masters C (1995) Intracellular production of $\beta$ A4 amyloid of Alzheimer's disease: modulation by phosphoramidon and lack of coupling to the secretion of the amyloid precursor protein. Biochemistry 34:8091-8098.

Gabuzda D, Busciglio J, Yankner BA (1993) Inhibition of $\beta$-amyloid production by activation of protein kinase C. J Neurochem 61: 2326-2329.

Garlick PJ, Marshall I (1972) A technique for measuring brain protein synthesis. J Neurochem 19:577-583.

Golde TE, Estus S, Younkin LH, Selkoe DJ, Younkin SG (1992) Processing of the amyloid protein precursor to potentially amyloidogenic derivatives. Science 255:728-730.

Haass C, Hung AY, Selkoe DJ (1991) Processing of $\beta$-amyloid precursor protein in microglia and astrocytes favors an internal localization over constitutive secretion. J Neurosci 11:3783-3793.

Haass C, Schlossmacher MG, Hung AY, Vigo-Pelfrey C, Mellon A, Ostazewski BL, Lieberburg I, Koo EH, Schenk D, Teplow DB, Selkoe DJ (1992) Amyloid $\beta$-peptide is produced by cultured cells during normal metabolism. Nature 359:322-325.

Haass C, Capell A, Citron M, Teplow DB, Selkoe DJ (1995) The vacuolar $\mathrm{H}^{+}$-ATPase inhibitor bafilomycin A1 differentially affects proteolytic processing of mutant and wild-type $\beta$-amyloid precursor protein. J Biol Chem 270:6186-6192.

Hardy J (1997) Amyloid, the presenilins and Alzheimer's disease. Trends Neurosci 20:154-159.

Hung AY, Haass C, Nitsch RM, Qui WQ, Citron M, Wurtman RJ, Growdon JH, Selkoe DJ (1993) Activation of protein kinase C inhibits cellular production of the amyloid $\beta$-protein. J Biol Chem 268: 22959-22962.

Iwatsubo T, Odaka A, Suzuki N, Mizusawa H, Nukina N, Ihara Y (1994) Visualization of $A \beta 42 / 43$ and $A \beta 40$ in senile plaques with end-specific $\mathrm{A} \beta$ monoclonals: evidence that an initially deposited species is $\mathrm{A} \beta 42$ 43. Neuron 13:45-53.

Jacobsen JS, Spruyt MA, Brown AM, Sahasrabudhe SR, Blume AJ, Vitek MP, Muenkel HA, Sonnenberg-Reines J (1994) The release of Alzheimer's disease $\beta$ amyloid peptide is reduced by phorbol treatment. J Biol Chem 269:8376-8382.

Jarrett JT, Berger EP, Lansbury PT (1993) The carboxy terminus of the $\beta$ amyloid protein is critical for the seeding of amyloid formation: Implications for the pathogenesis of Alzheimer's disease. Biochemistry 32:4693-4697.

Kikkawa U, Takai Y, Miyake R, Nishizuka Y (1983) Protein kinase C as a possible receptor protein for tumor-promoting phorbol esters. J Biol Chem 258:11442-11445.

Knauer MF, Soreghan B, Burdick D, Kosmoski J, Glabe CG (1992) Intracellular accumulation and resistance to degradation of the Alzheimer amyloid A4/ $\beta$ protein. Proc Natl Acad Sci USA 89:7437-7441.

Kochman K, Kerdelhue B, Ostrowska A, Chomike L, Domanski E, Justisz M (1982) Biosynthesis, in vivo, of gonadotropin-releasing hormone in the hypothalamus of normal and ovariectomized female rats. Mol Cell Endocrinol 25:193-198.

Krause JE, Advis JP, McKelvy JF (1982) In vivo biosynthesis of hypothalamic luteinizing hormone releasing hormone in individual freerunning female rats. Endocrinology 111:344-346.

Krause JE, Reiner AJ, Advis JP, McKelvy JF (1984) In vivo biosynthesis of $\left[{ }^{35} \mathrm{~S}\right]$ and $\left[{ }^{3} \mathrm{H}\right]$ substance $\mathrm{P}$ in the striatum of the rat and their axonal transport to the substantia nigra. J Neurosci 4:775-785.

Martin BL, Schrader-Fischer G, Busciglio J, Duke M, Paganetti P, Yankner BA (1995) Intracellular accumulation of $\beta$-amyloid in cells expressing the Swedish mutant amyloid precursor protein. J Biol Chem 270-26727-26730.

Naidu A, Quon D, Cordell B (1995) $\beta$-amyloid peptide produced in vitro is degraded by proteinases released by cultured cells. J Biol Chem 270:1369-1374.

Newton A (1995) Protein kinase C: structure, function, and regulation. J Biol Chem 270:28495-28498.

Nichols RA, Haycock JW, Wang JKT, Greengard P (1987) Phorbol ester enhancement of neurotransmitter release from rat brain synaptosomes. J Neurochem 48:615-621.

Nishizuka Y (1995) Protein kinase C and lipid signaling for sustained cellular responses. FASEB J 9:484-496.

Nitsch RM, Slack BE, Wurtman RJ, Growdon JH (1992) Release of
Alzheimer amyloid protein derivatives stimulated by activation of muscarinic acetylcholine receptors. Science 258:304-307.

Oltersdorf T, Ward P, Henriksson T, Beattie EC, Neve R, Lieberburg I, Fritz LC (1990) The Alzheimer amyloid precursor protein: identification of a stable intermediate in the biosynthetic/degradative pathway. J Biol Chem 265:4492-4497.

Perez RG, Squazzo SL, Koo EH (1996) Enhanced release of amyloid $\beta$-protein from codon 670/671 "Swedish" mutant $\beta$-amyloid precursor protein occurs in both secretory and endocytic pathways. J Biol Chem 271:9100-9107.

Pike CJ, Burdick D, Walencewicz AJ, Glabe CG, Cotman CW (1993) Neurodegeneration induced by $\beta$-amyloid peptides in vitro: the role of peptide assembly state. J Neurosci 13:1676-1687.

Qiu WQ, Borth W, Ye Z, Haass C, Teplow DB, Selkoe DJ (1996) Degradation of amyloid $\beta$-protein by a serine protease- $\alpha_{2}$-macroglobulin complex. J Biol Chem 271:8443-8451.

Qiu WQ, Ye Z, Kholodenko D, Seubert P, Selkoe DJ (1997) Degradation of amyloid $\beta$-protein by a metalloprotease secreted by microglia and other neural and non-neural cells. J Biol Chem 272:6641-6646.

Reaume AG, Howland DS, Trusko SP, Savage MJ, Lang DM, Greenberg BD, Siman R, Scott RW (1996) Enhanced amyloidogenic processing of the $\beta$-amyloid precursor protein in gene-targeted mice bearing the Swedish familial Alzheimer's disease mutations and a "humanized" A $\beta$ sequence. J Biol Chem 271:23380-23388.

Reith MEA, Schotman P, Gispen WH (1978) Measurements of in vivo rates of protein synthesis in brain, spinal cord, heart and liver of young versus adult rats, intact versus hypophysectomized rats. J Neurochem 30:587-594.

Rockenstein EM, McConlogue L, Tan H, Power M, Masliah E, Mucke L (1995) Levels and alternative splicing of amyloid $\beta$ protein precursor (APP) transcripts in brains of APP transgenic mice and humans with Alzheimer's disease. J Biol Chem 270:28257-28267.

Routtenberg A, Colley P, Linden D, Lovinger D, Murakami K, Sheu FS (1986) Phorbol ester promotes growth of synaptic plasticity. Brain Res 378:374-378.

Savage MJ, Iqbal M, Loh T, Trusko S, Scott RW, Siman R (1994) Cathepsin G: localization in human cerebral cortex and generation of amyloidogenic fragments from the $\beta$-amyloid precursor protein. Neurosci 60:607-619.

Savage MJ, Kawooya JK, Pinsker LR, Emmons TL, Mistretta S, Siman R, Greenberg BD (1995) Elevated A $\beta$ levels in Alzheimer's disease brain are associated with selective accumulation of $\mathrm{A} \beta_{42}$ in parenchymal amyloid plaques and both $\mathrm{A} \beta_{40}$ and $\mathrm{A} \beta_{42}$ in cerebrovascular deposits. Amyloid Int J Exp Clin Invest 2:234-240.

Selkoe DJ (1996) Amyloid $\beta$-protein and the genetics of Alzheimer's disease. J Biol Chem 271:18295-18298.

Seubert P, Vigo-Pelfrey C, Esch F, Lee M, Dovey H, Davis D, Sinha S, Schlossmacher M, Whaley J, Swindlehurst C, McCormack R, Wolfert R, Selkoe D, Lieberburg I, Schenk D (1992) Isolation and quantification of soluble Alzheimer's $\beta$-peptide from biological fluids. Nature 359:325-327.

Shoji M, Golde TE, Ghiso J, Cheung TT, Estus S, Shaffer LM, Cai XD, McKay DM, Tinter R, Frangione B, Younkin SG (1992) Production of the Alzheimer amyloid $\beta$ protein by normal proteolytic processing. Science 258:126-129.

Siman R, Mistretta S, Durkin JT, Savage MJ, Loh T, Trusko S, Scott RW (1993) Processing of the $\beta$-amyloid precursor: multiple proteases generate and degrade potentially amyloidogenic fragments. J Biol Chem 268:16602-16609.

Siman R, Durkin JT, Husten EJ, Savage MJ, Murthy S, Mistretta S, Chatterjee S, Dembofsky B, Poorman R, Greenberg BD (1995) Genesis and degradation of $\mathrm{A} \beta$ protein by cultured human neuroblastoma cells. In: Research advances in Alzheimer's disease and related disorders (Iqbal K, Mortimer JA, Winblad B, Wisniewski HM, eds), pp 675-684. Chichester, England: Wiley.

Sperk G, Singer EA (1982) In vivo synthesis of substance P in the corpus striatum of the rat and its transport to the substantia nigra. Brain Res 238:127-135.

Thinakaran G, Teplow DB, Siman R, Greenberg B, Sisodia SS (1996) Metabolism of the "Swedish" amyloid precursor protein variant in neuro2a (N2a) cells: evidence that cleavage at the " $\beta$-secretase" site occurs in the Golgi apparatus. J Biol Chem 271:9390-9397.

Tienari PJ, Ida N, Ikonen E, Simons M, Weidemann A, Multhaup G, Masters CL, Dotti CG, Beyreuther K (1997) Intracellular and secreted 
Alzheimer $\beta$-amyloid species are generated by distinct mechanisms in cultured hippocampal neurons. Proc Natl Acad Sci USA 94:4125-4130.

Torrens Y, Michelot R, Beaujouan JC, Glowinski J, Bockaert J (1982) In vivo biosynthesis of ${ }^{35} \mathrm{~S}$-substance $\mathrm{P}$ from ${ }^{35} \mathrm{~S}$-methionine in the rat striatum and its transport to the substantia nigra. $J$ Neurochem 38:1728-1734.

Vigo-Pelfrey C, Lee D, Keim P, Lieberburg I, Schenk DB (1993) Characterization of $\beta$ - amyloid peptide from human cerebrospinal fluid. J Neurochem 61:1965-1968.

Wasco W, Bupp K, Magendantz M, Gusella JF, Tanzi RE, Solomon F (1992) Identification of a mouse brain cDNA that encodes a protein related to the Alzheimer disease-associated amyloid $\beta$ protein precursor. Proc Natl Acad Sci USA 89:10758-10762.

Weidemann A, König G, Bunke D, Fischer P, Salbaum JM, Masters CL,
Beyreuther K (1989) Identification, biogenesis and localization of precursors of Alzheimer's disease A4 amyloid protein. Cell 57:115-126.

Wertkin AM, Turner RS, Pleasure SJ, Golde TE, Younkin SG, Trojanowski JQ, Lee VM-Y (1993) Human neurons derived from a teratocarcinoma cell line express solely the 695-amino acid amyloid precursor protein and produce intracellular $\beta$-amyloid or A4 peptides. Proc Natl Acad Sci USA 90:9513-9517.

Yamaguchi H, Sugihara S, Ishiguro K, Takashima A, Hirai S (1995) Immunohistochemical analysis of $\mathrm{COOH}$-termini of amyloid beta protein $(\mathrm{A} \beta)$ using end-specific antisera for $\mathrm{A} \beta 40$ and $\mathrm{A} \beta 42$ in Alzheimer's disease and normal aging. Amyloid Int J Exp Clin Invest 2:7-16.

Zlokovic BV, Ghiso J, Mackic JB, McComb JG, Weiss MH, Frangione B (1993) Blood-brain barrier transport of circulating Alzheimer's amyloid $\beta$. Biochem Biophys Res Commun 197:1034-1040. 